\title{
THE EFFECT OF INSURGENCY ON EDUCATION IN THE NORTH-EASTERN NIGERIA CASE OF BOKO HARAM
}

\author{
HASSAN, Umaru' ${ }^{1}$, ALH. DAUDA, Moh'd ${ }^{2}$, MOH'D, Ibrahim Dibal ${ }^{3}$ \& SALE, Auwal Liman ${ }^{4}$ \\ ${ }^{(1,2,3)}$ Federal Polytechnic Damaturu, School of Science and Technology, Department of Statistic \\ (4) Adamawa Polytechnic Numann, Adamawa State. \\ Email: simj2015@yahoo.com, umaruh@ rocketmail.com, 08065290329
}

DOI: 10.31364/SCIRJ/v6.i10.2018.P1018570

http://dx.doi.org/10.31364/SCIRJ/v6.i10.2018.P1018570

\begin{abstract}
Right from the outbreak of violence that has caused the death of thousands of people and subsequent attack on schools, teachers and children are in disarray in the affected areas. UNICEF estimated that not less than 2,295 teachers had been killed, in Nigeria and neighboring countries in recent violence by Boko Haram. This research work intends to examine the consequence of Boko Haram's activities on education. What could be the effect of the growing fear that some of these girls and women in captivity were radicalized on their educational pursuit? In this research, a well-structured questionnaire and interview methods was employed to sort for responses. A sample of Two thousand (2000) people whom are assumed to be a former Boko Haram abductees or members are to be used in the study by employing a purposeful sampling technique to the 21 registered Internally Displaced Persons (IDP's) camps and those living with their relatives across the northeast. To gain much success, soldiers should be banned from using schools as military base to avoid such schools being targeted. Government should deploy enough security at schools in the North-East so as to ensure children are not deprived of education in schools or safe learning centers There is a need for government also ensure parents and relatives of the missing girls are updated on the efforts to bring back their loved ones lack of which only contributes to their sufferings. This study is expected to guide in decision making and policy formulation as it's relate to victims of boko Haram.
\end{abstract}

Keywords: boko haram, insurgency, education

\section{INTRODUCTION}

Each country in the world seeks to a high quality of life and education for its citizenry, strong and diversified economic base, internal cohesion and political stability. This cannot be achieved without peaceful coexistence and enabling environment. Boko Haram's attacks on education has led to destruction of schools, also Teachers and students alike have suffered. "The conflict has left nearly 1 million children with little or no access to school, and Nigeria's security forces have contributed to the problem by using schools as military bases, Boko Haram's increasingly brutal assaults on schools, students, and teachers since 2009 in Borno, Yobe, Adamawa and Kano states". Between the years 2009 and 2015, Boko Haram's attacks destroyed more over 910 schools and forced not less than 1,500 to close up as reported by HRW. Nigeria's Minister of Education, Adamu Adamu, has said "2,295 teachers were killed in attacks by insurgents in the North-east". Nigeria (premium times, $6^{\text {th }}$ June, 2018) and another 19,000 forced to flee in fear of being killed. The sect has abducted over 2,000 people, some of whom are women and girls, including large number of students. (EDT Nigeria, 2016).

Boko Haram happens to be one of the most unique, unpredicted and complex sect's crises Nigeria has ever faced with since Independence. "The peculiarity of the group in Nigeria is not in its criminality but the sectarian nature of its agenda, which make it different from the dynamics of resource-driven localized violent conflicts between different ethnic groups in Plateau state, or the ethnic claims of insurgent groups such as the O'odua People's Congress (OPC), the Movement for the Emancipation of the Niger Delta (MEND) and the Movement for the Actualization of the Sovereign State of Biafra (MASSOB)". (Mac-Antoine, 2014).

The group Jama'atu Ahlus-Sunnah Lidda'Awati Wal Jihad, known all over the world as Boko Haram, is an extremist Islamic group in Nigeria that has caused havoc on our people in northeastern part of Nigeria including Abuja, and some parts of chad, Cameroon and Niger. Various conflicting reports have grown up around Boko Haram, and its origins, motivations, and future plans remain a matter of debate by scholars. Femi, (2014). 
Dr Ahmad Murtada of the Islamic Studies Department, University of Bayero, Kano has noted in his research of the group that the name of the movement should not be understood literally from the Hausa, but rather as meaning "traversing the Western system of education is haram". Ahmad, (2012). But remote villages who do not understand the affairs of states are mostly affected by boko haram activities.

\section{LITERATURE REVIEW}

The origins of Boko Haram is traced to a group of Muslim youth who worshipped at the Alhaji Muhammadu Ndimi Mosque in Maiduguri for years. In 2002, some of these youths (not yet known as Boko Haram) declared "the state and the Islamic establishment to be intolerably corrupt and irredeemable as against the teaching of Islam". The group declared to get on hijra (a withdrawal along the lines of the Prophet Muhammad's(SWA) withdrawal from Mecca to Medina). They moved from Maiduguri, Borno state to a place called Kanama in Yobe state, close to the border with Niger republic, to establish a community run on Islamic principles. The leader, Mohammed Ali, adopted an ideology and called on other Muslims to join to him is the return to a life under "true" Islamic law, which aims at making a more decent society away from the corrupt and indecent establishments. In December 2003, the group and the neighboring community had a dispute on fishing right in a pond which led to a confrontation between the Nigeria police and the sect. Consequently, lead to the killing of 270 members including Mohammed Ali. Andrew, (2012). and Shehu, (2014). The few survivors of the "Nigerian Taliban" went back to Maiduguri, where they settled with the other members who originated at the Ndimi mosque. Mohammed Yusuf as the leader of Maiduguri group, who was born in Girgir village of Yobe State then decided on building the group's own mosque in Maiduguri Shehu, (2014). This mosque, was built on land to the North-West of the town, close to the railway station, the plot of land was given to them by Yusuf's father-in-law, Baba Fugu Mohammed which was named the Ibn Taimiyyah Masjid. The group was apparently left alone by the authorities, breaking every laws of the state with impunity and it expanded into other states, including Bauchi, Yobe, and Adamawa State among others.

An expectedly, the whole world was shake when 276 schoolgirls were kidnapped by Boko Haram and the world reacted by pledging support for the Government of Nigeria and also led to the formation of Bring Back Our Girls campaign (BBOG). As most of those school girls from Chibok are still missing, many people are hopeful that other kidnapped women/children would receive a welcome back. Chris K.((July 2011) and Kelvin, (2016)).

The communities believed that the government led de-radicalization process for those who spends years with Boko Haram in captivity, requires a necessary precondition for their integration. As these victims reach internally displaced person (IDP) camps and an attempt to return them to their villages of origin, it has been observed that many of them are suffering from acute mental distress resulting from sexual, psychological and physical violence suffered in captivity, UNICEF and International alert,(2016) and Kevin Sieff, (2016)

The problem of the victims is where, when and how to start life, considering the fact that stigmatization may also play some part in their ability to interact well with the general public. Hence the need for government and humanitarian actors (e.g. the United Nation (UN), non-governmental organizations (NGOs) and community base Organizations (CBO) should enhance service provision and access to service for IDPs. "The fear is that they have been converted to Boko Haram's ideology," said Mohammed Ali Guja, the chairman of Bama Local Gov't. "They are now a different person." Kevin Sieff ,( 2016): "We think they have been more or less brainwashed these children,” said Maj. Gen. Lucky Irabor, (Kevin Sieff ,( 2016):

\section{CAUSES OF BOOK HARAM}

Abdulkarim Mohammed, a researcher on Boko Haram added that, violent unrest in Nigeria are mostly due to "the fallout of frustration with corruption and the attendant social malaise of poverty and unemployment." Eric, (2011).

"Boko Haram took root against a backdrop of poverty. But this does not explain why it emerged in Borno state and not in Kaduna or Kano states, which were the epicenters of radical Islamic and religious violence in the 1980s and 1990s" Autumn, (2003). "The neighboring region of Diffa in the Republic of Niger is much poorer. But Diffa is better governed, less corrupt and less affected by a sense of marginalization and social injustice" Autumn, (2003)

Boko Haram's opposition is not only to Western education but also to Western culture and science, a position Mohammed Yusuf made clear in an interview conducted by the BBC, he stated that "the belief that the earth is spherical in shape is a sharp contradiction 
to Islamic thought and therefore should be rejected along with Darwinism and the theory that rain comes from water evaporated by the sun". (Stefanie D. and Philipp S., (2014): Ironically, Nigerian academician Hussain Zakariya told BBC News that "Yusuf is a graduate, educated and very proficient in English" (Stefanie D. and Philipp S., (2014):

\section{KIDNAPPINGS OF SCHOOL AGE CHILDREN}

Boko Haram has long used kidnapping as a weapon of war against Nigerian state, forcibly conscripting young boys and men into their ranks and using women and young girls as sex slaves and suicide bombers, Agence France-Press, (2016): for some of us who lives in the troubled zone, we have witnessed several kidnappings by Boko Haram in schools franging from that of GGSSS Konduga, Chibok, Damasak, and the lateset one in Dapchi. One of the most difficult thing is to distinguish between ideology driven Boko Haram or grievance-driven attacks, politically motivated attacks and political militias that may or may not claim to be affiliates of the movement. The April, 2014 kidnapping of over 200 school girls in Chibok, some still missing, drew a new and wider international attention on Nigeria and Boko Haram activities, its triggered offers of assistance by Nigeria's and international partners. MacAntoine, (2014).

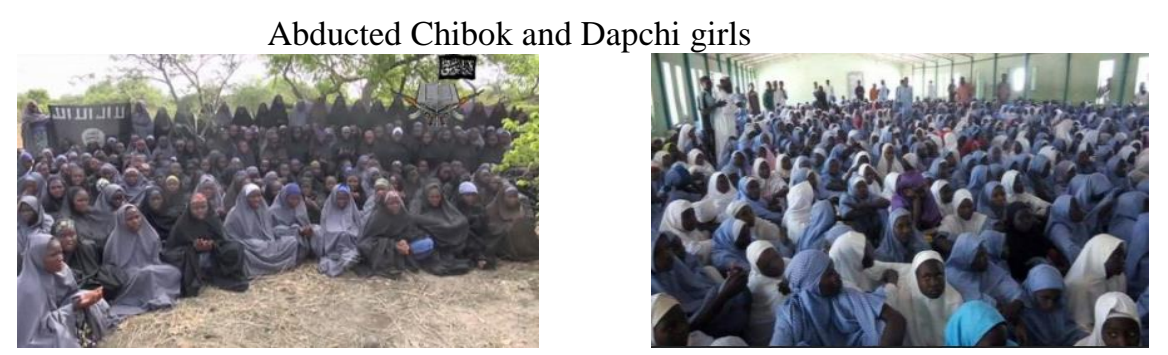

Female students of the GGSS Chibok Girls Secondary School, Dapchi, Yobe State during head count

Image caption: From the section Africa (SaharaReporters)

Nigeria's government has been accused of being too slow in its response to the kidnapping of more than 200 girls from a school in Chibok before the coming of this current administration

Before the kidnapping of chibok girls, there was much abduction made by Boko Haram in some isolated Schools, like that of Government Girls College Konduga. According to HRW's (Human Right Watch) investigation, "Boko Haram occupied Zanna Mobarti Primary School in Damasak in November 2014, after taking control of the town, More than 300 students were inside the school. The militants banned teaching in English and forced their captives to learn the Koran. When soldiers from neighboring Chad and Niger advanced into Damasak in March 2014, Boko Haram militants fled the town, taking with them the 300 school children and around 100 more women and children who were also being held captive". (CONOR G., (2016) and Sahara Reporters,( March, 2015). Damasak residents who were interviewed by the Agency France Press (AFP) reported that "None of the kidnapped school children had been returned and said they had not spoken out on the abduction due to pressure from the government, which was already struggling to manage the embarrassment of losing the Chibok girls. The administration of former President Goodluck Jonathan denied reports of the Damasak kidnapping in March 2015”. Sahara Reporters,( March, 2015)

Boko Haram's destructions and killing on schools , and students, and teachers in northeast Nigeria have had a damaging impact on education. "The conflict has left nearly 1 million children with little or no access to school, and Nigeria's security forces have contributed to the problem by using schools as military bases, putting children at further risk of attack from the Islamist armed group", (HRW, ( 2016).

"In its brutal crusade against western-style of education, Boko Haram is robbing an entire generation of children in north- east Nigeria of their education," Mausi Segun, http://www.hrw.org/news/2016/04/11/nigeria "The government should urgently provide appropriate schooling for all children affected by the conflict."HRW,( 2014).

Government and non-Governmental organization recognized camps host only $30 \%$ of the children, where some educational services are provided by volunteer teachers. The remaining $70 \%$ are with friends and family members, with little or no access to schooling. https://aljazeera.com/news/Africa/2014/02/students-killed-nigeria-school-attack-201442251111212151892.html.

Bala Ajiya, a reporter with the Vanguard newspaper who visited the Specialist Hospital Damaturu, to see the victims of Buni Yadi attack told Reuters by phone that the death toll had raised to 59, after counting the bodies as they came in, Joe, (2014) 


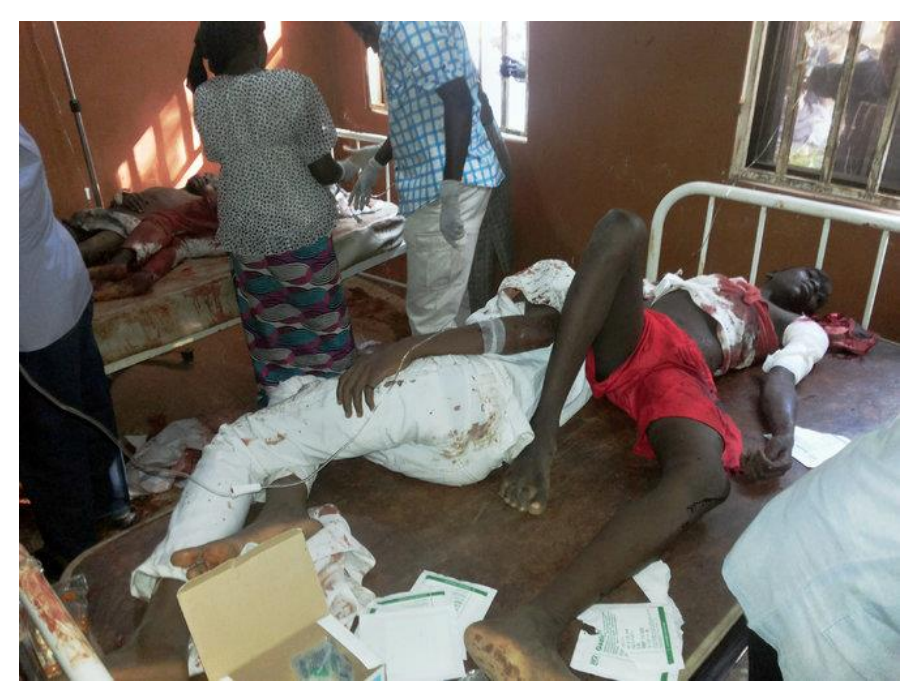

Photo: Hospital workers treated survivors of a suicide bombing at a high school in Potiskum, Nigeria, Credit to Adamu Adamu/Associated Press

Upon inauguration of President Muhammadu Buhari in May 2015, he said "I would not claim Boko Haram was defeated until all captives held by the group, including the Chibok girls, were returned". But in December 2015, he claimed that "the militants had been "technically" defeated by a Nigerian military offensive and had resorted to guerrilla-style suicide attacks". However, the strong holds of Boko Haram has been destroyed by the Nigerian army in Sambisa, most of them are now looking for hide out. A good number of Boko Haram have fled to Gwoza Mountains popularly known as Mandara Mountains for hiding.

\section{Negotiation}

Talking with insurgents is often a necessary first step toward defeating them or reaching an acceptable compromise. Negotiation can continue even when Boko haram is still heating back as must often be done even as insurgents shoot at U.S. soldiers, and they in turn, shoot at them. (Mac-Antoine, 2014 and Daniel Byman (2009)). As a result of resent negotiation between Boko Haram and Nigerian Government, 21 chibok girls were freed in the north-eastern Nigerian town of Banki, near the border with Cameroon, a source close to the negotiations said on condition of anonymity. Mac-Antoine, (2014).another release of the chibok girls and also that of university lecturers along with ten (10) other women is a land mark. Its our hope that Dapchi girls could be released as soon as possible.

\section{OBJECTIVE OF THE STUDY}

The objectives of the study are to investigate the following:

1 To investigate the effect of Boko Haram activities on the psychology of the people in the area towards western education.

2 The effect of Boko Haram activities on educational infrastructure

3 The effect of Boko Haram activities on Pupil/students enrolment

$4 \quad$ The effect of Boko Haram activities on Brain drain on the side of Teachers

5 To investigate the level of involvement of school age pupils in Boko Haram

6 To sort for general opinion on how to end the crises

\section{Significance of the study}

This study will be of help in identifying the problems and needs of the boko Haram victims, which will in turn help the government and non-governmental Organizations to plan and strategize on how to help and re-integrate the victims back to school and also back into the society at large.

\section{Research methodology}


In this research, a sample of Two thousand (2000) people whom are former Boko Haram abductees or members were used in the study by employing a purposeful sampling technique was administered in the 21 registered IDP's camps across the north-east and those living with their family and friends. A sample of two hundred security personnel who formerly participated in the fight against Boko Haram were also sampled.

A well-structured questionnaire and interview methods was employed to sort for their response. 9 trained personals (researchers) was used to administer such instrument. A learned Islamic Scholars was also involved in the course of this study.

\section{RESULTS}

Objectives 1

The finding revealed that a significant number of villages in some part of the Northern and central Borno have less interest in western education this is confirmed by the response to the question "Do parents sent their wards to school?" $75 \%$ of the respondents agreed to send their children to school and 25\% don't. More so even when there are at the IDP camps there some parents that have refused to send their children to schools. Dalori 1 camp has the higher rate of such.

\section{Objectve II}

\section{Infrastructure}

The infrastructure in the states especially Borno state in Particular has been pulled down completely in all most all the Local Gov'ts, However, re-construction is ongoing, the schools in various Local Governments are now housed in what is called learning centers in the metropolis (Maiduguri). There are five learning centers, eg, Gov’t College Maiduguri is Housing GSS Damasak, GSSSS, Bama, GDSS Gwoza, ETC.

\section{Objective III}

The students enrolment has been affected by the activities of boko haram, as it can be seen in the figures below.

Figure1: The distribution of students enrolment in some selected secondary schools in Yobe state

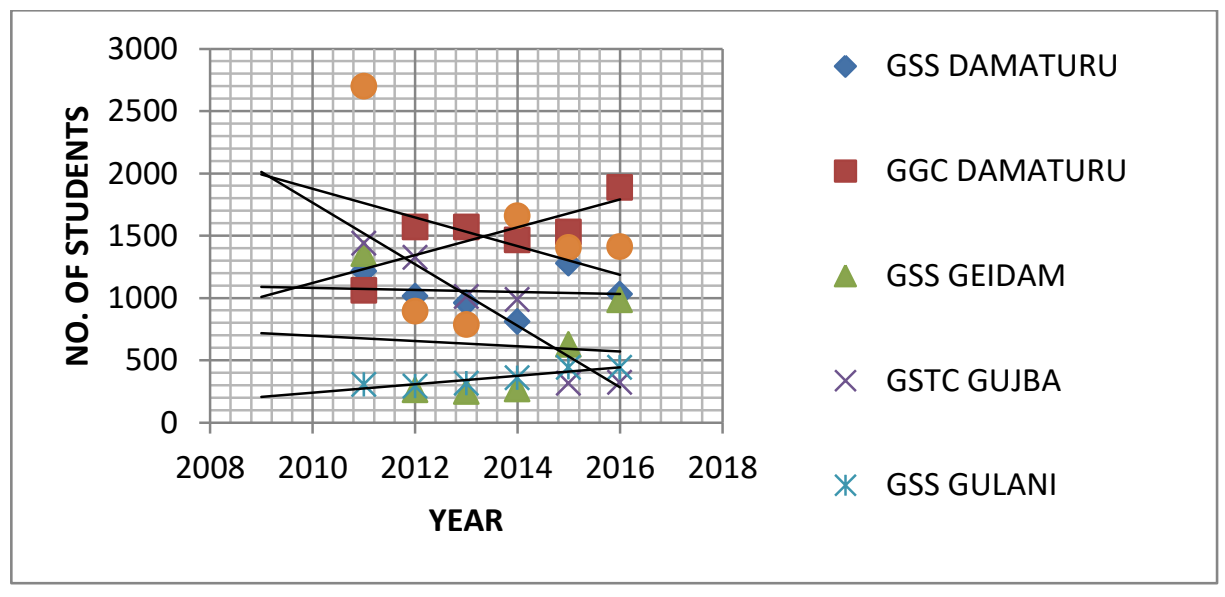

SOURCE: Ministry of education

We can see that schools in most affected areas are on the decline in terms of enrolment of students which is worst in figure 2. 
Figure2: The distribution of student's enrolment in some selected secondary schools in Borno state

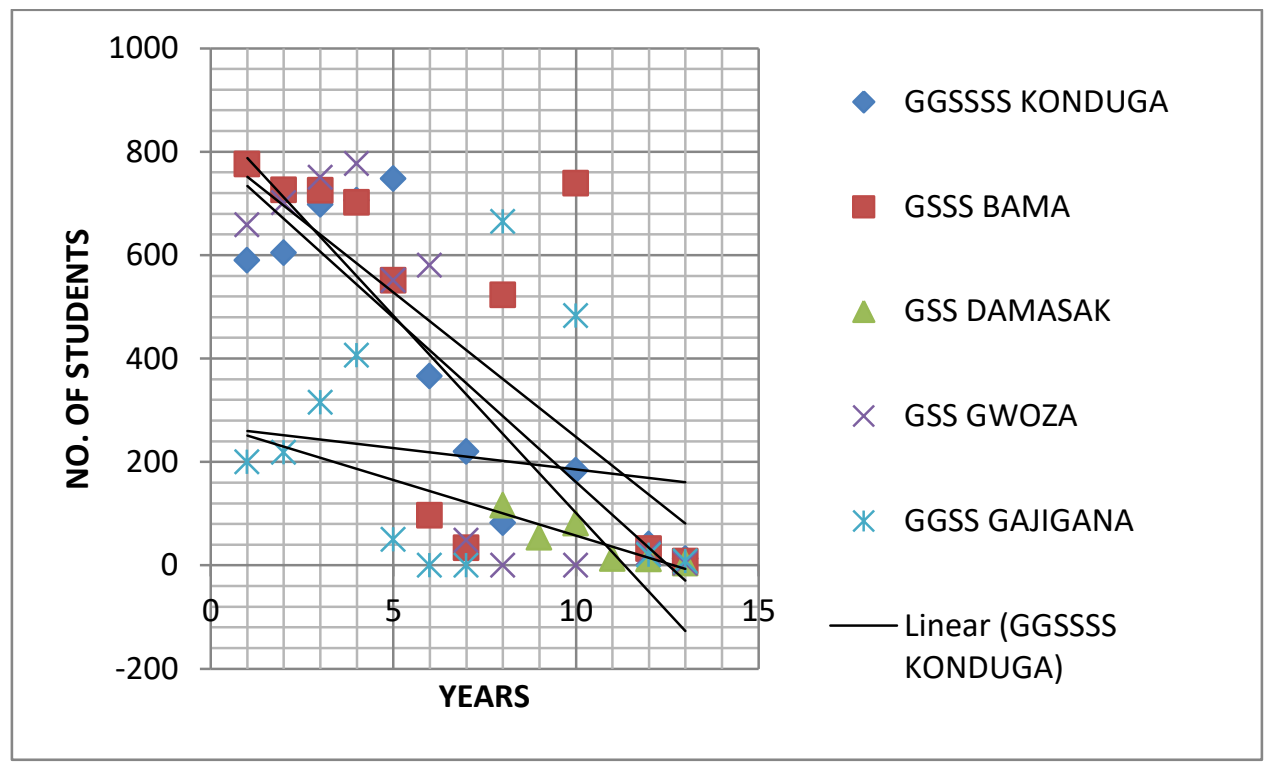

SOURCE: BORNO STATE MINISTRY OF EDUCATION

\section{Objective IV}

The number of teachers to students is adequate not because the qualified teacher has not left the state but because of some retired teachers are back to the profession to help the sector.

Dalori camp for example, teachers are on shifting, and those that will teach today will not come the next day. Similar case is happening in Gwoza town as reported by the participating teachers.

\section{Objective V}

It's unfortunate to state here that the findings of this research work reveals that $95 \%$ of the boko haram are between the ages of 13- 30 years. The findings revealed that less than 5\% of them (boko haram) are above 40years as reported by those who had direct contact with members of boko haram we interviewed at various IDP camps we visited.

\section{Objective VI}

On how to end this crises of boko haram, $85 \%$ of the people interview were of the opinion that negotiation is the best way to end the menace. While $13 \%$ agree to crush them by military might.

\section{SUMMARY}

This study have revealed the consequence of Boko haram activities on education in the Northeast Nigeria as obtained through questionnaire and interview methods administered on some selected IDP Camps in Borno and Yobe States. The finding reveal among other things the level of destructions on educational infrastructures, students enrolment ETC.

\section{RECOMMENDATION}

1 Declaring state of emergency on education in the zone by compulsory education up to high level for all school age.

2 Creating conducive teaching and learning environment 
3 Re-training of teachers

4 Securing all schools to avoid further abduction of students.

5 We finally recommend that reports on security issues from civilian should be treated with high degree of responsibility

\section{Reference}

Ahmad.( 2013). "Boko Haram: Its Beginnings, Principles and Activities in Nigeria". April 2012 (al-Qira'at Journal [for African and Islamic Studies], no.12, pp.12-25, trans. SalafiManhaj.com 2013). Retrieved 26 February 2014.)

Agence France-Press, (2016): ' Women and the Boko Haram insurgency’. telegraph News. Https://www,crisis group.org/Africa/westaferia/Nigeria/Nigeria-women-and boko haram-insurgency

Andrew Walker (2012): United States Institute of Peace. Special Report 308.

Autumn (2003), 'Education, Poverty and Terrorism: Is There a Causal Connection?', Journal of Economic Perspectives, Vol. 17, No. 4, pp. 119-44.

Boko Haram at a Glance (Feature, 29 January 2015)- See more at: https://africacheck.org/factsheets/factsheet-explaining-nigeriasboko-haram-and-its-violent-insurgency/\#sthash.2ZLQ3Jv8.dpuf

Chris Kwaja (July 2011): "Nigeria's Pernicious Drivers of Ethno-Religious Conflict". Africa Security Brief (Africa Center for Strategic Studies) (14). Archived from the original on "Boko Haram's Rise in Nigeria Sparks Civil War Fears". Voanews.com. 2012-01-21. Retrieved 2013-07-06.

CONOR GAFFEY(2016): Boko Haram Kidnapped 300 Schoolchildren In Damasak: HRW on 3/31/16 AT 10:52 AM. https:// aljazeera.com/news/Africa/2014/02/students-killed-nigeria-school-attack-201442251111212151892.html.

Daniel Byman (2009).”Talking with insurgents": a guide for the perplexed. The washington quarterly report.

EDT Nigeria, (2016): Northeast Children Robbed of Education, April 11, 2016 7:53PM

Eric Guttschuss (2011): "Analysis: Understanding Nigeria's Boko Haram radicals". www.irinnews.org. IRIN. 18 July 2011. Retrieved 12 March 2012

Femi Owolade (2014) Boko Haram: How a Militant Islamist Group Emerged in Nigeria March 27, 2014 at 5:00 am http://www.gatestoneinstitute.org/4232/boko-haram-Nigeria

Human Right Watch April, (2014).Boko Haram's attacks on schools, students and teachers in northeast Nigeria have had a devastating impact on education. HUMAN RIFGT WATCH APRIL, 2016. Nigeria: Northeast Children Robbed of Education

JOE Hemba,(2014): Nigerian Islamists kill 59 pupils in boarding school attack DAMATURU, NIGERIA https:// aljazeera.com/news/Africa/2014/02/students-killed-nigeria-school-attack-201442251111212151892.html.

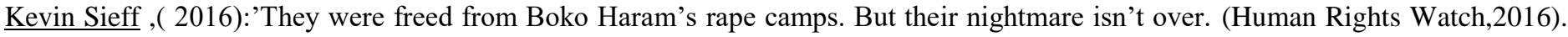
https://www.washintonspot.com/...boko haram.../dbi2aab0-e54fa9ce-681055c7.. 
Marc-Antoine Pérouse de Montclos: (2014): Nigeria's Interminable Insurgency? Addressing the Boko Haram Crisis Africa Programme | September 2014

Reporters without Borders,(2012). "Innermost thoughts of the Islamist Group Boko Haram," Paris [2012]

Richard Joseph(2011): insecurity and counter-insurgency in Africa why is it important and what needs to happen in 2012 ?

Shehu Sanni, (2014) See more at: https://africacheck.org/factsheets/factsheet-explaining-nigerias-boko-haram-and-its-violentinsurgency/\#sthash.2ZLQ3Jv8.dpuf.

Stefanie D. and Philipp S., (2014): “ Boko Haram: Barrage against western Values’ http://p.dw.com/p/lE5ad

Sahara Reporters,( March, 2015)." Boko Haram kidnaps 400 women in Damasak". As reported by Punch Newspaper, March 25,2015

UNICEF and International alert,(2016): Bad blood: 'Perception of children born out of conflict-related sexual violence and women and girls associated with book Haram in North East Nigeria. http://www.unicef.org/Nigeria/Nigeria_Badblood_EN_2016.pdf 